\title{
Samtaler om alkohol i allmennpraksis
}

Å snakke om alkoholbruk når det kan være relevant for pasientens helseproblemer, er et godt alternativ til regelmessig kartlegging av alkoholvaner.

Høyt alkoholforbruk er en viktig årsak til øt sykelighet og dødelighet. I Norge har alkoholforbruket økt betydelig, og helsemyndighetene anbefaler regelmessig screening for risikofylt eller skadelig alkoholforbruk. Men forskningen har vist at slik screening sjelden gjøres og at effekten er usikker. Vi trenger derfor bedre egnede strategier.

I mitt doktorarbeid startet vi med en fokusgruppestudie hvor vi utforsket fastlegenes grunner for å spørre om alkoholbruk. Vi fant at de oftest spurte når det kunne være relevant for pasientens helseproblemer, for eksempel ved søvnforstyrrelser, psykiske plager, hypertensjon eller fordøyelsesplager. Iblant spurte de rutinemessig, for eksempel ved utstedelse av ulike attester eller ved svangerskap. Dette har vi sammenfattet $\mathrm{i}$ begrepet «pragmatisk case-finding».

I den neste fokusgruppestudien utforsket vi faktorer som kunne fremme eller hemme «pragmatisk case-finding». Blant de viktigste fremmende faktorene var klinisk relevans og tidsfaktoren, hvor lange forløp gir nye sjanser. Den siste delstudien bygger på journaldata fra 20000 pasienter fulgt i 4-17 år. Vi fant blant annet en viss sammenheng mellom antall B-resepter og antall nye sykmeldinger og fremtidig alkoholbrukslidelse.

Allmennleger bør snakke oftere med sine pasienter om alkoholbruk. Doktorarbeidet viser at dette kan oppnås ved bedre kunnskap om kliniske situasjoner hvor alkohol kan være relevant og ved målrettet screening i noen situasjoner - altså «pragmatisk case-finding».

Torgeir Gilje Lid giljelid@gmail.com

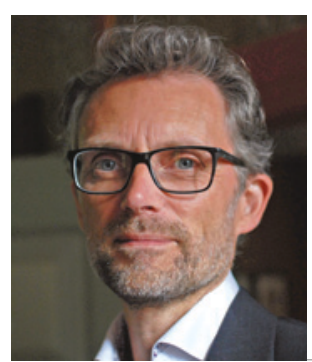

Torgeir Gilje Lid. Foto: Vilde Lid Aavitsland

\section{Disputas}

Torgeir Gilje Lid disputerte for ph.d.-graden ved Universitetet i Bergen 14.6. 2016. Tittelen på avhandlingen er Addressing alcohol in general practice.

\section{Proliferasjonsmarkører i infiltrerende astrocytomer}

\begin{abstract}
Immunhistokjemiske proliferasjonsmarkører har både diagnostisk og prognostisk verdi i infiltrerende astrocytomer med WHO-grad II og WHO-grad III.
\end{abstract}

Hjernesvulster er klassisk sett blitt diagnostisert og gradert ut fra en rekke histologiske trekk som er definert av WHO-klassifikasjonssystemet. Én av svakhetene ved klassifikasjonssystemet er at de oppgitte kriteriene i stor grad er basert på subjektiv vurdering. Konsekvensen av dette er at det ikke alltid er samsvar mellom patologene - verken når det gjelder diagnose eller malignitetsgrad.

I mitt doktorarbeid har vi undersøkt bruken av immunhistokjemiske proliferasjonsmarkører for å se om de har diagnostisk eller prognostisk verdi i diffuse astrocytomer, som er den vanligste formen for primær hjernesvulst. Mer spesifikt har vi sett på følgende antistoffer: Ki67/MiB-1, MCM2, mitosin, $\mathrm{pHH} 3$, survivin og DNA-topoisomerase II $\alpha$. Etter hvert ble det også inkludert IDH1-mutasjonstatus, som nå spiller en viktig diagnostisk rolle i det reviderte WHO-klassifikasjonssystemet fra 2016.

I våre studier var økt uttrykk av markørene assosiert med høyere malignitetsgrad og dårligere overlevelse. Videre ble det også vist at proliferasjonsmarkørene kan ha en prognostisk tilleggsverdi som er uavhengig IDH1-mutasjonstatus. Disse funnene tyder på at proliferasjonsmarkører har både diagnostisk og prognostisk verdi og dermed potensielt kan brukes i hverdagsdiagnostikken av astrocytomer. Mer nøyaktig diagnostikk av hjernesvulster og bedre forståelse av pasientens prognose er en fordel i den kliniske hverdagen, siden det kan ha betydning for behandlingsvalget.

\section{Rosilin K. Varughese}

rosilinv@gmail.com

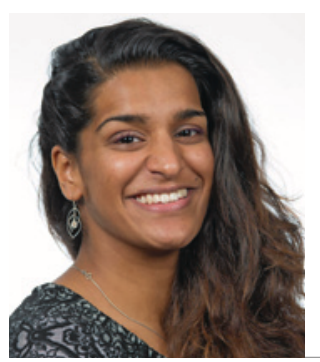

Rosilin K. Varughese. Foto: Jørn Ove Sæternes

Disputas

Rosilin K. Varughese disputerte for ph.d.graden ved Norges teknisk-naturvitenskapelige universitet 4.10. 2016. Tittelen på avhandlingen er Prognostic and diagnostic markers in astrocytomas WHO grade II and III. 